\title{
MEASUREMENTS OF WATER PRESSURE IN MOULINS AS PART OF A MOVEMENT STUDY OF THE WHITE GLACIER, AXEL HEIBERG ISLAND, NORTHWEST TERRITORIES, CANADA
}

\author{
By Almut Iken * \\ (Axel Heiberg Expedition, McGill University, Montreal, Quebec, Canada)
}

\begin{abstract}
Aвstract. In 1970 water pressure was measured in several moulins on the White Glacier. Pressure variations in some moulin channels extended over the full measuring range of the instruments $\left(\mathrm{O}_{-1} \mathrm{I}\right.$ and $\mathrm{O}-2$ bar above atmospheric pressure), even at depths of less than $50 \mathrm{~m}$ below the surface. Measurements at different depths showed that total pressure variations were sometimes greater than this. The pressure data are compared with variations in the surface velocity of the glacier.

Résumé. Mesures de la pression de l'eau dans les moulins glaciaires réalisées au cours d'une étude sur les mouvements du White Glacier, Axel Heiberg Island, Territoire du Nord-Ouest, Canada. En 1970, la pression de l'eau a été mesurée dans plusieurs moulins du White Glacier. Les variations de pression dans quelques chenaux sousglaciaires ont couvert la totalité de l'échelle de mesure des instruments (o-1 et $\mathrm{O}-2_{2}$ bars au-dessus de la pression atmosphérique), même à des profondeurs inférieures à $50 \mathrm{~m}$ en-dessous de la surface. Des mesures à différentes profondeurs ont montré que les variations totales de pressions étaient quelquefois supérieures à ces limites. Les pressions mesurées sont comparées à la vitesse superficielle du glacier.

Zusammenfassung. Messungen des Wasserdruckes in Gletschermühlen im Zusammenhang mit einer Untersuchung der Bewegung des White Glacier, Axel Heiberg Island, Northwest Territories, Canada. 1970 wurde in verschiedenen Gletschermühlen des White Glacier der Wasserdruck gemessen. In Tiefen von z.T. weniger als $50 \mathrm{~m}$ unter der Gletscheroberfläche wurden in den Mühlen Druckschwankungen bis zur Grösse des gesamten Messbereichs ( $0-1$ und $o_{-2}$ bar Überdruck) registriert. Aus Messungen in verschiedenen Tiefen ergibt sich, dass in einigen Fällen die Druckschwankungen insgesamt noch grösser waren. Die gemessenen Drucke werden mit den Schwankungen der Oberflächengeschwindigkeit des Gletschers verglichen.
\end{abstract}

\section{INTRODUCTION}

The movement of White Glacier has been observed since ig6o. In r 969 the work was concentrated on measuring daily fluctuations of the glacier surface velocity. Velocity fluctuations appeared to correlate with fluctuations in the discharge of a surface and an englacial stream. This suggested that velocity fluctuations might be caused by variations in the water pressure at the bed of the glacier (Müller and Iken, in press). In I 970 attempts were made to measure variations of water pressure in moulins while observing glacier movement. From the pressure meastrements it was also hoped to learn something of the slope of the moulin channels. The location of the moulins studied can be seen in Figure I. Moulins 1 and $3-5$ developed in 1970 in new crevasses; the smallest ( $\mathrm{I}$ ) was approximately $0.60 \mathrm{~m}$ in diameter, the largest (4) over I $\mathrm{m}$ by the end of the season. They penetrated cold ice: the mean annual air temperature at the lower end of White Glacier is approximately $-20^{\circ} \mathrm{C}$. It is however probable that the bed of the glacier is at the pressure melting point (Müller, I963). Inexpensive remote-reading Bourdon pressure gauges were used. The measuring ranges were $0-1$ and $0-2$ bar above atmospheric pressure with error limits of $3 \%$ to $8 \%$. The gauges were enclosed in waterproof cylindrical containers $88 \mathrm{~mm}$ in diameter and 1 io $\mathrm{mm}$ in length attached to $300 \mathrm{~m}$ lengths of 2-conductor cable. This type of equipment was chosen for reasons of economy, since occasional losses were considered inevitable.

\section{Pressure observations}

Significant run-off from the glacier did not start until 9 July. In the period 9 to I 7 July the drainage channels on the glacier were developing and some new moulins formed. Measurements in the moulins were begun on 15 July. In the upper parts of the moulins there were

* Present address: Geographisches Institut der Eidgenössischen Technischen Hochschule Zürich, 8oo6 Zürich, Switzerland. 


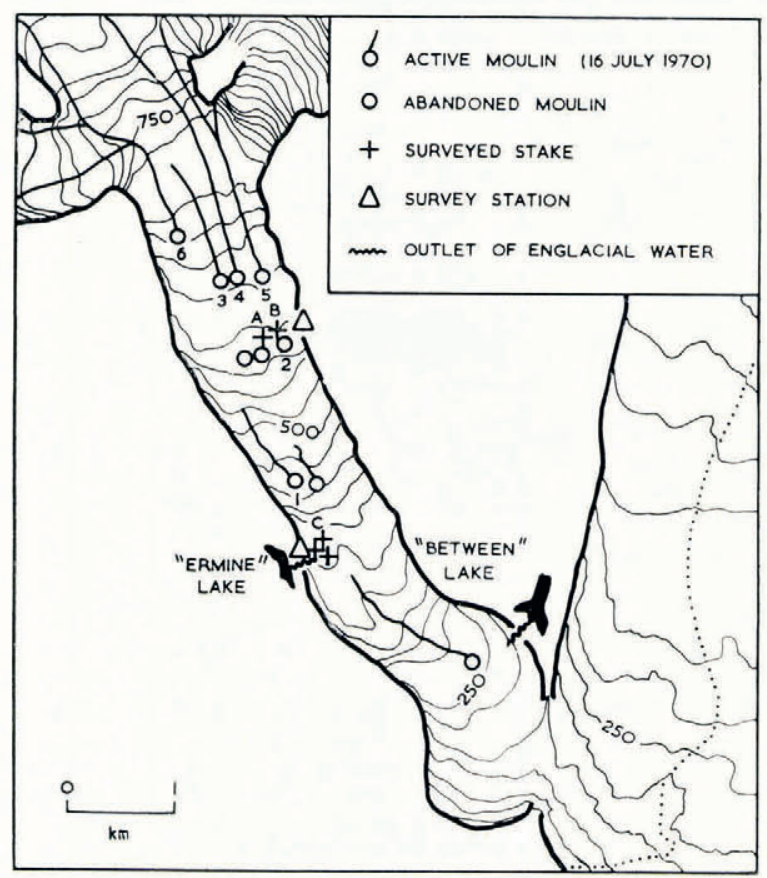

Fig. I. Map of White Glacier with location of moulins and surveyed stakes.

no measurable deviations from atmospheric pressure. Below a certain depth the pressure increased rapidly as more cable was lowered into the moulin. The pressures measured at different depths in moulin 2 are given in Table I. Figure 2 shows the slope of the channel as inferred from these pressure readings. The calculation of vertical distances was based on the assumption that a pressure of 0.098 bar corresponded with I $\mathrm{m}$ of water above the gauge. This assumption is correct for the data of 16 July when the channel had stopped flowing. On I 5 July when the moulin was still active, frictional energy dissipation (and possibly a change of kinetic head with distance) was to be expected. Accordingly this part of the plotted

TABLE I. WATER PREsSURE AT Different LENGTHS OF CABLE BELOW THE GLACIER SURFACE IN MOULIN 2

$\begin{array}{ccc}\text { Time } & \begin{array}{c}\text { Length of cable } \\ \mathrm{m}\end{array} & \begin{array}{c}\text { Pressure } \\ \text { (above atmospheric pressure) } \\ \text { 15 July 17.15 h }\end{array} \\ & 43 & 0.00 \\ & 44 & 0.09 \\ & 49 & 0.51 \\ & 54 & 0.71 \\ & 59 & 1.06 \\ & 64 & 1.48 \\ & 69 & 1.87 \\ \text { I5 July 20.20 h } & 72 & 2.09 \\ & 59 & 1.29 \\ & 64 & 1.75 \\ \text { 16 July 07.50 h } & 69 & 2.10 \\ & 79 & 0.18 \\ \text { I6 July 17.00 h } & 83 & 0.37 \\ & 70 & 0.29 \\ & 78.5 & 1.10\end{array}$


channel is probably less steep than the actual slope. Measurements yielded the same data, within the limits of error, when repeated after a few minutes. After periods of the order of an hour, however, the observed pressures differed considerably. The pressure readings obtained at different times at a fixed depth in moulin 4 are plotted in Figure 3 . In this and other moulins, pressure reached a maximum in the afternoon or evening.

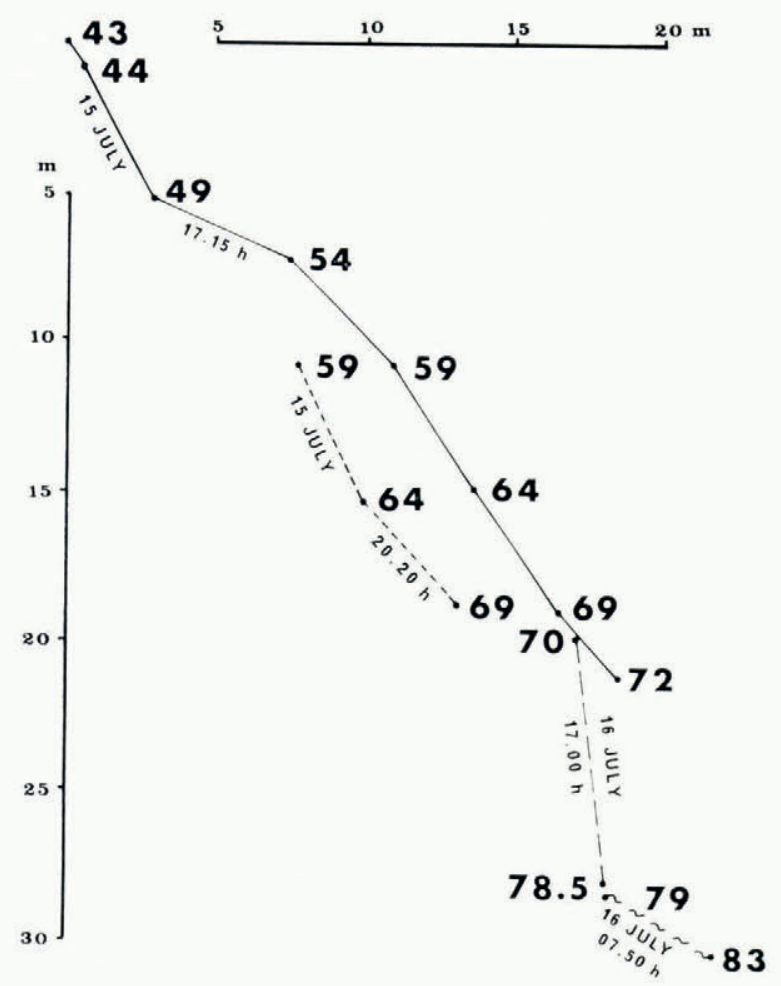

Fig. 2. Approximate slope of the channel of moulin 2 inferred from pressure readings. The numbers on the slope indicate the length of cable below the glacier surface in metres. The axes show the scale of the drawing and do not refer to distance from the origin on the ice surface.

Following the opening of a large transverse crevasse $65^{\circ} \mathrm{m}$ up the glacier, and the development of new moulins $(3,4$, and 5$)$, pressure variations of more than 2 bar from one day to the next were observed in moulin 2 although it had been abandoned and all major streams had ceased draining into an adjacent crevasse system. From measurements at different depths in this moulin it can be inferred that the difference in pressure between I 8 July and $\mathrm{I} 7.00 \mathrm{~h}$ on $3^{1}$ July at $78.5 \mathrm{~m}$ length of cable below the surface was at least 3.7 bar. It is likely, however, that even diurnal variations were occasionally greater. On 3 I July, a day of strong melt, a very rapid pressure increase was observed. Pressure at $49 \mathrm{~m}$ of cable below the surface rose from atmospheric pressure to over I bar within an hour.

\section{Discussion}

In general a measured pressure consists of the mean pressure head with superimposed fluctuations and the pressure which results from the interaction of water flowing over the pressure gauge housing. It is likely that in turbulent water a gauge adopts many different orientations during a series of measurements. The regularity of the pressure readings suggests 
that the gauges were recording the undisturbed mean pressure head. In any case it is safe to assume that the steady increase of pressure with depth or time represented an increase in the mean pressure head. Considerable pressure variations in the abandoned moulin 2 suggest a largely interconnected englacial or subglacial drainage system. There must have been a preexisting connection between the abandoned moulin 2 and the new moulins $650 \mathrm{~m}$ up glacier, since the water pressure rose in moulin 2 on the same day that the surface stream ceased to feed it. Since I968 there had been no moulins above moulin 2 except moulin 6 and another one, close to the eastern margin, which was blocked and water-filled at the beginning of the melt season of 1970 . Unless the new crevasse with moulins $3^{-5}$ met a sub-surface channel of moulin 6 , we are inclined to follow Lliboutry ( 1968 ) in the assumption of a pre-existing network of subglacial cavities. Another sign of partly subglacial drainage of White Glacier is the extreme turbidity of water emerging from the ice tunnel at "Between" lake and also from a crack at the glacier margin at "Ermine" lake. The latter outlet flowed only at times of relatively strong melt. No other outlets of moulin water were found in 1968, I969, or 1970, with the exception of a few short lived streams. This also points to the interconnection of all moulin channels.

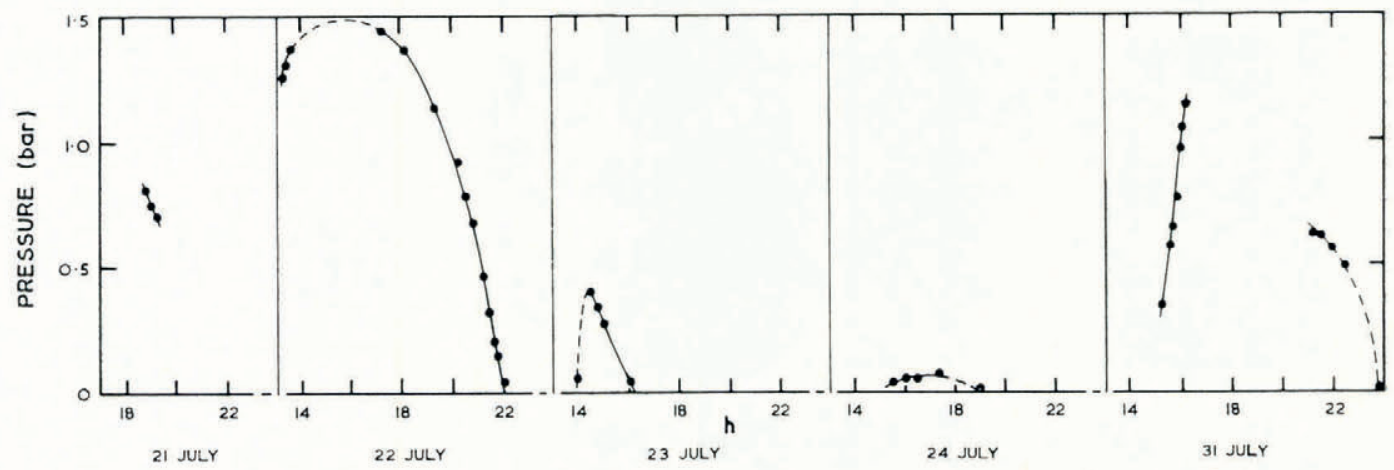

Fig. 3. Water pressure in moulin 4 at $48 \mathrm{~m}$ of cable below the surface. Pressures are in bars above atmospheric pressure.

Immediate subglacial drainage of water when thermal bore holes reached bedrock was observed in a temperate glacier by Reynaud (unpublished). On the other hand it took over a year until a connection was established between the drainage system of South Leduc Glacier and an artificial shaft reaching the glacier bed from the rock below (Mathews, 1964). The temperature close to the ice-rock interface was in this case well below the pressure melting point.

\section{COMPARISON OF WATER PRESSURE AND GLAGIER MOVEMENT DATA}

No pressures above atmospheric pressure were recorded at the greatest depths reached on I 7 and I 8 July and between 25 and 30 July. On these days the glacier surface velocity measured near "Ermine" lake was also low except on 30 July (Table II). 30 July was the first day with significant run-off after a period of snowfall and fog and low glacier flow $\left(25^{-29}\right.$ July). On the other hand on 23 July after a period of high glacier velocity the movement was relatively slow. If a causal relationship were assumed between water pressure in moulins and glacier velocity, the different response on 30 July might be explained by recovery from an unusual longitudinal stress gradient that had built up during the period of accelerated movement of the lower part of the glacier only. On a short time scale there was no good correlation between glacier surface velocity at "Ermine" lake and water pressure in the moulins $2.3 \mathrm{~km}$ up glacier from "Ermine" lake. The times of maximum pressure often did not coincide with the times of maximum velocity and differed by up to 8 hours. This difference may in part be 
TAble II. Glacier surface velocity near "Ermine" Lake during the PERIOD OF WATER PRESSURE MEASUREMENTS

\begin{tabular}{|c|c|c|}
\hline \multirow[b]{2}{*}{ Time interval } & \multicolumn{2}{|c|}{$\begin{array}{l}\text { Velocity } \\
\mathrm{mm} / \mathrm{day}\end{array}$} \\
\hline & $\begin{array}{c}I \text { stake } \\
I \text { oo } m \\
\text { from the margin }\end{array}$ & $\begin{array}{l}\text { Average of } 2 \\
\text { stakes } 200 \mathrm{~m} \\
\text { from the margi }\end{array}$ \\
\hline $30 \mathrm{~h}$ to 16 July o9.30 $\mathrm{h}$ & $111 \neq 1$ & $200 \pm 1$ \\
\hline $\mathrm{h}$ to $17 \mathrm{July} 09.30 \mathrm{~h}$ & $94 \pm 0$ & $163 \pm 1$ \\
\hline $\mathrm{h}$ to 18 July $08.30 \mathrm{~h}$ & $80 \pm 1$ & $142=1$ \\
\hline $\mathrm{h}$ to $19 \mathrm{July}$ 10.00 $\mathrm{h}$ & $86 \pm I$ & $148+1$ \\
\hline $\mathrm{h}$ to $20 \mathrm{July} 07.00 \mathrm{~h}$ & $96 \pm 1$ & $175 \pm 2$ \\
\hline $\mathrm{h}$ to $2 \mathrm{I}$ July $08.30 \mathrm{~h}$ & $129 \pm 1$ & $234 \pm 1$ \\
\hline $\mathrm{h}$ to $22 \mathrm{July} 08.30 \mathrm{~h}$ & $109 \pm 1$ & $190 \pm 1$ \\
\hline $\mathrm{h}$ to $23 \mathrm{July} 12.00 \mathrm{~h}$ & $118 \pm 1$ & $212 \pm 2$ \\
\hline h to 24 July $09.30 \mathrm{~h}$ & $89 \pm 2$ & $14^{8} \pm 3$ \\
\hline $\mathrm{h}$ to $25 \mathrm{July} 10.00 \mathrm{~h}$ & $89 \pm 2$ & $151 \pm 5$ \\
\hline $\mathrm{h}$ to 26 July $13.00 \mathrm{~h}$ & $78 \pm 0$ & $148 \pm 2$ \\
\hline $\mathrm{o}$ h to 27 July i $1.00 \mathrm{~h}$ & $67 \pm 1$ & $I 3 I \pm I$ \\
\hline $\mathrm{h}$ to 28 July $09.30 \mathrm{~h}$ & $63 \pm 1$ & $122 \pm 2$ \\
\hline $\mathrm{h}$ to 29 July $09.00 \mathrm{~h}$ & $75 \pm \mathrm{I}$ & I $39 \pm 3$ \\
\hline $\mathrm{h}$ to 30 July o8.30 h & $77 \pm 2$ & $142 \pm 3$ \\
\hline h to 3 I July $10.00 \mathrm{~h}$ & $95 \pm \mathrm{I}$ & $180 \pm 1$ \\
\hline h to I Aug.08.30 h & & $220 \pm 5^{*}$ \\
\hline
\end{tabular}

15 July $09.30 \mathrm{~h}$ to 16 July $09.30 \mathrm{~h}$ 16 July $09 \cdot 30 \mathrm{~h}$ to 17 July $09 \cdot 30 \mathrm{~h}$ 17 July $09.30 \mathrm{~h}$ to 18 July $08.30 \mathrm{~h}$ 18 July $08.30 \mathrm{~h}$ to 19 July $10.00 \mathrm{~h}$ 19 July $10.00 \mathrm{~h}$ to 20 July $07.00 \mathrm{~h}$ 20 July $07.00 \mathrm{~h}$ to $2 \mathrm{I}$ July $08.30 \mathrm{~h}$ 2 I July $08.30 \mathrm{~h}$ to 22 July $08.30 \mathrm{~h}$ 22 July $08.30 \mathrm{~h}$ to 23 July $12.00 \mathrm{~h}$ 23 July $12.00 \mathrm{~h}$ to 24 July $09.30 \mathrm{~h}$ 24 July $09.30 \mathrm{~h}$ to 25 July $10.00 \mathrm{~h}$ 25 July io.0o h to 26 July $13.00 \mathrm{~h}$ 26 July $13.00 \mathrm{~h}$ to 27 July i $1.00 \mathrm{~h}$ 27 July II .oo h to 28 July $09.30 \mathrm{~h}$ 28 July $09.30 \mathrm{~h}$ to 29 July og.0o h 29 July $09.00 \mathrm{~h}$ to 30 July o8.30 h 30 July $08.30 \mathrm{~h}$ to $3 \mathrm{I}$ July $10.00 \mathrm{~h}$ 3I July 10.00 h to I Aug.08.30 h

It is expected that the actual errors are in $55 \%$ of the cases not greater than the error limits shown.

* Only I stake was surveyed.

\section{LEVEL (mm)}

$$
\begin{aligned}
& \text { OF CREVASSE } \\
& \text { STREAM }
\end{aligned}
$$
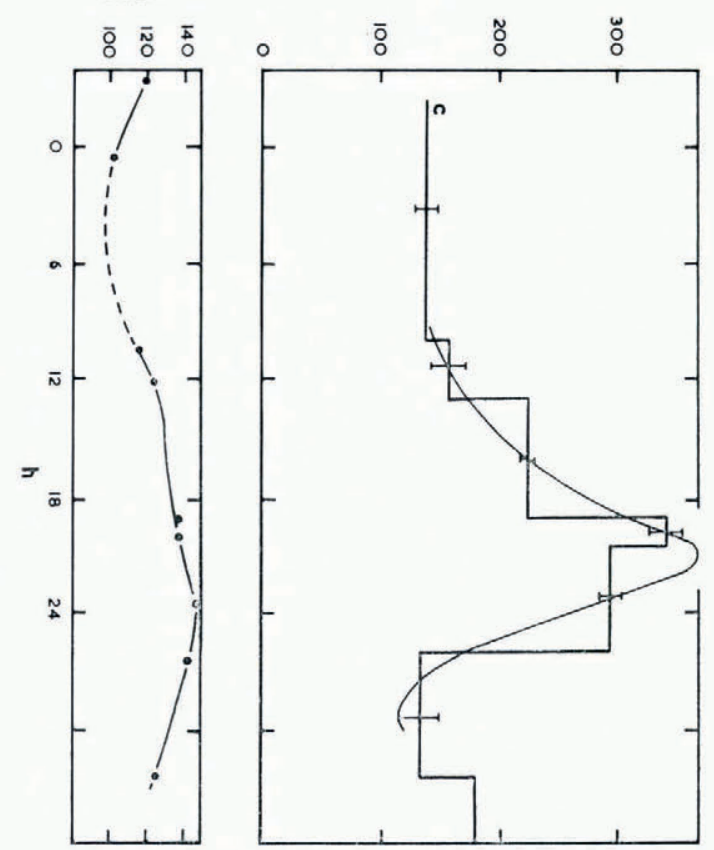

GLACIER SURFACE VELOCITY $(\mathrm{mm} / \mathrm{d})$

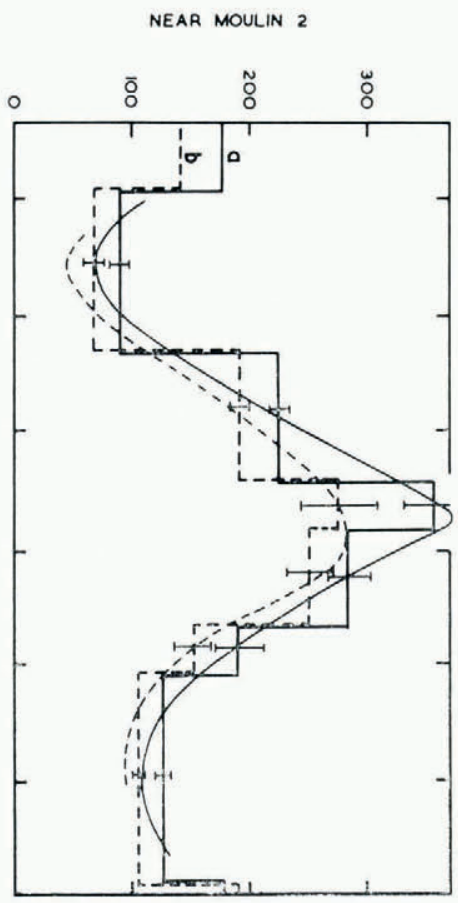

IN MOULIN 2 AT $49 \mathrm{~m}$ CABLE LENGTH BELOW SURFACE

Fig. 4. Water pressure in moulin 2, glacier surface velocities, and discharge of a turbid stream from a crevasse at "Ermine" lake, 3 I July 1970. Pressures are in bars above atmospheric pressure. 
due to the distance between the two observation sites. A new surveying site was therefore prepared in the vicinity of the moulins. Unfortunately there was only one more day (3 I July) when the glacier velocity rose to a sharp maximum and when the melt was sufficiently strong so that readings could be obtained from the gauges. On this day the time of maximum pressure in the abandoned moulin 2 agrees well with the time of maximum glacier velocity in the vicinity of the moulins, while the glacier velocity near "Ermine" lake reached the maximum 3-4 hours later and approximately $2-3$ hours before the time of maximum discharge of turbid water from the nearby crevasse (Fig. 4).

\section{Conclusions}

The observations are too few to draw definite conclusions about the relationship between water pressure in moulins and glacier velocity. A relationship seems to exist between measurements made at different places when periods of one or more days are considered. The simultaneous movement observations on $3^{\mathrm{I}}$ July suggest that the time of daily maximum velocity varies over the glacier depending on the local water pressure. No perfect correlation is expected since the velocity pattern presumably depends also on other variables such as the size of areas of high water pressure and changes of the longitudinal stress gradient in the glacier. The work showed that considerable pressure variations occur even in abandoned moulins, and that some information about the slope of moulin channels can be obtained with relatively simple equipment. It would be better to use gauges with a higher range than $0-2$ bar above atmospheric pressure. It would then be possible to cover a longer section of a moulin channel with one set of measurements and also to leave the gauge at the deepest point reached without the danger of damaging the instrument.

\section{Acknowledgements}

I am grateful to Dr Fritz Müller, scientific leader of the expedition, for his help and encouragement. The work in the field could not have been done without the able assistance of Susanne Pusback. This research was supported by a grant to Dr Müller from the National Research Council of Canada.

MS. received I Fanuary 1971 and in revised form 29 May 197 I

\section{REFERENCES}

Lliboutry, L. A. 1968. General theory of subglacial cavitation and sliding of temperate glaciers. Fournal of Glaciology, Vol. 7, No. 49, p. 2 I-58.

Mathews, W. H. I964. Water pressure under a glacier. Journal of Glaciology, Vol. 5, No. 38, p. 235-40.

Müller, F. 1963. Englacial temperature measurements on Axel Heiberg Island, Canadian Arctic Archipelago. Union Géodésique et Géophysique Internationale. Association Internationale d'Hydrologie Scientifique. Assemblée générale de Berkeley, $19^{-8}-3{ }^{1-8} 19^{6} 3$. Commission des Neiges et des Glaces, p. 168-80.

Müller, F., and Iken, A. In press. Velocity fluctuations and water regime of arctic valley glaciers. Union Géodésique et Géophysique Internationale. Association Internationale d'Hydrologie Scientifique. Commission de veiges et Glaces. Symposium on the hydrology of glaciers, Cambridge, 7-13 September 1969, organized by the Glaciological Society.

Reynaud, L. Unpublished. Prospection au Glacier d'Argentières, campagne 1958. Société Hydrotechnique de France. Section de Glaciologie. Comptes Rendus Ronéo des Séances, 20 février 1959. 